\title{
Research on Optimization Model of Residential District Planning
}

\author{
Jing Liu \\ School of Economics and Management \\ Jiangxi University of Science and Technology \\ Ganzhou, 341000, China \\ 764358838@qq.com
}

\begin{abstract}
In the light of the problems, ratio of residential district planning index based on the elementary mathematics, the method of establishing the index of residential district planning, small green area, small facilities area and road area of the village, and analyzes the effects of these indicators of community planning, village, under the condition of profit margin is solved by using the reasonable planning of residential district. Lingo software is used to solve the optimal index ratio of residential district planning, and excel is used to draw the polyline diagram before and after the optimization of residential district planning model, so as to solve the problem more perfectly. The optimal ratio of planning indicators of residential areas is obtained as follows: green area: facility area: $\operatorname{road}$ area $=5: 1: 3$. In addition, the most reasonable green area accounts for $35 \%$, the facility area accounts for $7 \%$, the road area accounts for $21 \%$, and the rest is the projected area of the building area accounts for $37 \%$.
\end{abstract}

Keywords-green space area; facility area; road area; residential district planning; optimization model

\section{INTRODUCTION}

The environment, service facilities and roads of the community are directly related to the housing price, while the area of the community is limited. The environment, roads and service facilities of the community occupy the area of the building and affect the housing area. The housing price and the area are directly related to the income of the community. At present, there are still some problems in the planning and design of many residential areas, such as small green area, high plot ratio, poor ventilation and lighting performance, which not only affects the satisfaction of buyers, but also restricts the development of the housing industry. How to seek the maximization of development profit by optimizing district planning and design under the condition of certain land use scale is a problem to be solved.

\section{LITERATURE REVIEW}

After consulting the literature on residential planning, we found that there are many methods to study residential planning, and there are many factors that affect residential planning, including national policies, the relationship between buildings and nature, planning philosophy, landscape design, architectural design to create a green living environment based on the needs of human beings. The existing research results are as follows:
(1) Research and analysis on planning and design of modern high-rise residential area. [1]. This paper takes Youngor International Garden in Suzhou as an example to make a detailed analysis of the planning and design of the modern high-rise residential district. The research includes the planning concept, landscape design, architectural design, and so on. The purpose of this paper is to summarize the methods of the residential district planning and design and provide a reference for other similar projects. This research has used the case analysis method.

(2) Research on residential services. [2]. During recent years there has been a large interest in residential service in Sweden. Several experiments and investigations have been carried out concerning various service facilities in residential districts and attempts to let the tenants themselves participate in the planning of this service. This article reports from an evaluation of the planning procedure in this district, where opinions and wants of the tenants have been continually collected in order to make the residential service as good as possible. The article mainly comprises a presentation of how the tenants participated in the planning process, an analysis of the reasons why this planning failed in some respects and a comparison to other research in this field.

(3) Research on modern residential areas. [3]. This paper takes the second-stage Guxi Shanshui Residential District in Dang Tu County as an example to analyze the characteristics of it from the aspects of function, traffic, landscape, and house types. And we explore the planning and design of the modern residential district by this research, and hope to make useful contributions to the development and construction of the future residential district planning and design

(4) Study on the planning of residential areas in postearthquake reconstruction projects. [4]. According to the analysis and the research on the residential environment concept and methods of the planning and design of the modern residential environment, it discusses residential environment planning and design scheme in the reconstruction after earthquake disasters. The article also points out that it should make the residential environment planning and design from such aspects as the reconstruction sites, the planning system, local culture, building and environment design, psychological reconstruction, and thus establishes good social and cultural 
environment so as to improve people's quality of their lives. At the same time, it briefly reviews the organization approach and overall ideas of the Wenchuan earthquake reconstruction planning. And some basic methods and strategies of the recovery are discussed in the article.

(5) Research on green building residential district planning. [5]. The thesis analyses the early stage of the planning and design in Taiyuan xicun renovation project from the green building perspective. It summarizes the strengths and shortages on the basis of Four Conservations and One Protection (area conservation, energy conservation, water conservation, material conservation and environmental protection). By analyzing the problems in planning and designing modern residential area, this thesis aims to provide some suggestions to the green building idea.

(6) Study of school district planning. [6]. The paper intends to research the planning and design of Hubei Institute of Fine Arts (HIFA)'s new Canglongdao campus. The new campus is envisioned as an eco-friendly, economical, functional and elegant garden-like campus with HIFA's unique characteristics. It can be roughly divided into five areas, viz. the administrative area, the teaching area, the residential area, the sporting area and the studio area. The campus buildings and landscaping borrow from traditional Chinese architecture and gardening. Its road and pedestrian systems are convenient and user-friendly.

( 7 ) Study on landscape planning and design of humanistic and ecological residential area. [7]. In order to accommodate residential change from "natural" to "cultural ecology" and to make green landscape more features, taking overall planning and design of Houma Huaxiang Scholarly Huayuan of Tongji University as example, on the basis of livable cities, the theme intention "scholarly culture and flowers" was concentrated to improve the comprehensive cultural series combing upgrade and build a characteristic landscape of scholarly poetry and painting doors and peony, lotus, crape myrtle three court, rich cultural implication was explored to build effective ways for residential landscape environment, organic integration of cultural landscape and natural eco-green was conducted to fully recognize the importance of cultural implication to theory and practice of urban residential landscape construction.

\section{Methodology}

The income of the residential area is related to the housing price and the building area. Appropriate indicators are selected to analyze the influencing factors of the housing price. Similarly, the influencing factors of the building area are analyzed. The optimization model is constructed according to the objective function of maximizing the income of real estate developers.

First of all, according to the problems in the residential income maximization, the purpose of the analysis of income is equal to the product, house prices and a building area of then impact on house prices to select three indicators, green space area, road area and facilities area respectively, among them, the three indicators are need is greater than the provisions of the state, and three indicators related to residential area number of habitable, and population and per capita living space. The larger the green area, road area and facility area, the better the quality of the community, and the more the residents like it. However, the area of the community is certain. If the green area, road area and facility area occupies too large an area, the building area is insufficient, and the income is too low, which does not meet the requirements.

Secondly, based on the above analysis, an optimization model with the goal of maximizing income and the constraint conditions of road area, green space area and facility area is established.

Finally, according to the established model, collect relevant data to analyze, investigate the index data of various buildings into the model, and use lingo software to get the ratio of maximum income and plot planning green area, facility area and road area.

\section{MODEL}

\section{A. Symbol description}

$S$ : Community developers' income

$P$ : Housing price in the community

$Q$ : The building area of the community

$g$ : The green area of the community

$r$ : The road area of the community

$S$ : The facility area of the community

$N$ : The number of residents in the community

$A$ : The total floor area of the community

$L$ : The number of floors in the community

\section{B. Buildup of model}

First, set up the target function. Residential income and housing prices and building area. The income of the community is equal to the house price times the floor area.

$$
S=P \times Q
$$

Secondly, constraint conditions are established. It can be known from the assumed conditions that green space area, road area and facility area are in direct proportion to the income of the community, and then:

$$
P=f(g, r, s)=k_{1} g+k_{2} r+k_{3} s
$$

$g$ is green area, $r$ is road area and $S$ is facility area. $k_{1}$ is the proportional coefficient between green space area and community income, $k_{2}$ is the proportional coefficient between road area and community income area, and $k_{3}$ is the proportional coefficient between facility area and community income. 
Assume the national per capita living area is $a m^{2}$. With the per capita living area stipulated by the state unchanged, the number of residents should be more to maximize income.

$$
N \geq \frac{Q}{a}
$$

Assume per capita green area is $b m^{2}$. To make the green area of the community meet the national standard, then the green area should be larger than the number of residents multiplied by the per capita green area, making the green area of the community more, so that consumers are more satisfied with the planning of the community.

$$
g \geq N \times b
$$

Suppose the per capita road area is .The green area should be larger than the number of residents multiplied by the per capita road area, so that the road area of the community is larger and consumers are more satisfied with the planning of the community.

$$
r \geq c \times N
$$

To make the area of community facilities to meet the national standards, access to information ${ }^{[3]}$. Assume the national per capita facility area is $d m^{2}$. The facility area should be larger than the number of residents multiplied by the per capita facility area, to make the facility area of the community more.

$$
s \geq d \times N
$$

According to the given conditions, the total area is certain.

$$
A=\frac{Q}{L}+g+r+s
$$

The final optimization model is

$$
\begin{aligned}
& \max S=P \times Q \\
& \text { s.t }\left\{\begin{array}{l}
P=k_{1} g+k_{2} r+k_{3} S \\
N \geq \frac{Q}{a} \\
g \geq N \times b \\
r \geq c \times N \\
S \geq d \times N \\
A=\frac{Q}{L}+g+r+s
\end{array}\right.
\end{aligned}
$$

\section{Data to be used}

TABLE I. PER CAPITA LIVING AREA, GREEN SPACE AREA, ROAD AREA AND FACILITY AREA

\begin{tabular}{|c|c|c|}
\hline name & number & unit \\
\hline Per capita living area in China & 40.8 & $m^{2}$ \\
\hline Per capita green space in China & 5 & $m^{2}$ \\
\hline Per capita road area in China & 3 & $m^{2}$ \\
\hline Per capita facilities in China & 1 & $m^{2}$ \\
\hline
\end{tabular}

TABLE II. DATA OF EIGHT REAL ESTATE INDICATORS

\begin{tabular}{|c|c|c|c|}
\hline $\begin{array}{c}\text { Real estate } \\
\text { name }\end{array}$ & $\begin{array}{c}\text { Huanrunwan } \\
\text { xiangfu }\end{array}$ & $\begin{array}{c}\text { Hengdadiji } \\
\text { ng }\end{array}$ & $\begin{array}{c}\text { Zhonghaibingj } \\
\text { iangyihao }\end{array}$ \\
\hline $\begin{array}{c}\text { Building } \\
\text { area/10000 }\end{array}$ & 42.7 & 28 & 16.15 \\
\hline $\begin{array}{c}\text { Green } \\
\text { area/10000 }\end{array}$ & 4.11 & 3.15 & 2.58 \\
\hline $\begin{array}{c}\text { Facility } \\
\text { area/10000 }\end{array}$ & 2.74 & 1.8 & 1.3 \\
\hline $\begin{array}{c}\text { Road } \\
\text { area/10000 }\end{array}$ & 2.58 & 1.25 & 0.56 \\
\hline $\begin{array}{c}\text { Number of } \\
\text { residents per } \\
\text { person }\end{array}$ & 10466 & 6800 & 3824 \\
\hline $\begin{array}{c}\text { Average } \\
\text { number of } \\
\text { floors }\end{array}$ & 10 & 10 & 8 \\
\hline $\begin{array}{c}\text { Area/10000 } \\
\text { House } \\
\text { prices/RMB }\end{array}$ & 13.7 & 9300 & 6.46 \\
\hline
\end{tabular}

TABLE III. DATA OF EIGHT REAL ESTATE INDICATORS

\begin{tabular}{|c|c|c|c|}
\hline $\begin{array}{c}\text { Real estate } \\
\text { name }\end{array}$ & $\begin{array}{c}\text { Yuanshengsh } \\
\mathrm{iji}\end{array}$ & $\begin{array}{c}\text { Biguiyuanlia } \\
\text { nfatianhui }\end{array}$ & $\begin{array}{c}\text { Lianfayongr } \\
\text { onghuafu }\end{array}$ \\
\hline $\begin{array}{c}\text { Building } \\
\text { area/10000 }\end{array}$ & 17.2 & 19.4 & 20.46 \\
\hline $\begin{array}{c}\text { Green } \\
\text { area/10000 }\end{array}$ & 1.87 & 2.33 & 2.64 \\
\hline $\begin{array}{c}\text { Facility } \\
\text { area/10000 }\end{array}$ & 1.24 & 1.31 & 1.2 \\
\hline $\begin{array}{c}\text { Road } \\
\text { area/10000 }\end{array}$ & 0.83 & 0.97 & 0.77 \\
\hline
\end{tabular}




\begin{tabular}{|c|c|c|c|}
\hline $\begin{array}{c}\text { Number of } \\
\text { residents per } \\
\text { person }\end{array}$ & 4504 & 3296 & 5000 \\
\hline $\begin{array}{c}\text { Average } \\
\text { number of } \\
\text { floors }\end{array}$ & 9 & 10 & 10 \\
\hline Area/10000 & 6.19 & 6.55 & 6.61 \\
\hline $\begin{array}{c}\text { House } \\
\text { prices/RMB }\end{array}$ & 8000 & 8500 & 12000 \\
\hline
\end{tabular}

\section{Solution of model}

Lingo software is used to bring the data into the model.

Obtain Huanrunwanxiangfu real estate maximum income for 40.51 million yuan. The green space area after optimization is 50.24 thousand $m^{2}$. The road space area after optimization is 31.4 thousand $m^{2}$. The facility space area after optimization is 10.47 thousand $m^{2}$. Floor area is 424 thousand $m^{2}$.

Obtain Hengdadijing real estate maximum income for 21.66 million yuan. The green space area after optimization is 35 thousand $m^{2}$. The road space area after optimization is 20.4 thousand $m^{2}$. The facility space area after optimization is 6.8 thousand $m^{2}$. Floor area is 277.4 thousand $m^{2}$.

Obtain Zhonghaibingjiangyihao real estate maximum income for 12.7 million yuan. The green space area after optimization is 29.8 thousand $m^{2}$. The road space area after optimization is 11.5 thousand $m^{2}$. The facility space area after optimization is 3.8 thousand $m^{2}$. Floor area is 156 thousand $m^{2}$.

Obtain Yuanshengshiji real estate maximum income for 11.77 million yuan. The green space area after optimization is 23.5 thousand $m^{2}$. The road space area after optimization is 13.5 thousand $m^{2}$. The facility space area after optimization is 3.8 thousand $m^{2}$. Floor area is 183.8 thousand $m^{2}$.

Obtain Biguiyuanlianfatianhui real estate maximum income for 15.22 million yuan. The green space area after optimization is 33.8 thousand $m^{2}$. The road space area after optimization is 9.9 thousand $m^{2}$. The facility space area after optimization is 3.3 thousand $m^{2}$. Floor area is 185 thousand $m^{2}$.

Obtain Lianfayongronghuafu real estate maximum income for 13.63 million yuan. The green space area after optimization is 25.7 thousand $m^{2}$. The road space area after optimization is 15 thousand $m^{2}$. The facility space area after optimization is 5 thousand $m^{2}$. Floor area is 204 thousand $m^{2}$. In summary, the data are shown in table 3 .

TABLE IV. SIX INDEX DATA OF REAL ESTATE AFTER OPTIMIZATION

\begin{tabular}{|c|c|c|c|c|c|c|}
\hline $\begin{array}{c}\text { Real } \\
\text { estate } \\
\text { name }\end{array}$ & $\begin{array}{c}\text { Buildi } \\
\text { area } \\
/ 1000 \\
0\end{array}$ & $\begin{array}{c}\text { Green } \\
\text { area } \\
/ 1000 \\
0\end{array}$ & $\begin{array}{c}\text { Facilit } \\
\text { y area } \\
/ 1000 \\
0\end{array}$ & $\begin{array}{c}\text { Road } \\
\text { area } \\
/ 1000 \\
0\end{array}$ & $\begin{array}{c}\text { House } \\
\text { prices } \\
/ \text { RMB }\end{array}$ & $\begin{array}{c}\text { Incom } \\
\text { e/100 } \\
\text { millio } \\
n\end{array}$ \\
\hline $\begin{array}{c}\text { Huanr } \\
\text { unwa } \\
\text { nxian } \\
\text { gfu }\end{array}$ & 42.7 & 5.24 & 1.05 & 3.14 & 8300 & 35.44 \\
\hline $\begin{array}{c}\text { Heng } \\
\text { dadiji } \\
\text { ng }\end{array}$ & 27.75 & 3.5 & 0.68 & 2.04 & 13800 & 38.64 \\
\hline $\begin{array}{c}\text { Zhong } \\
\text { haibin } \\
\text { gjiang } \\
\text { yihao }\end{array}$ & 15.6 & 2.98 & 0.38 & 1.15 & 15000 & 24.23 \\
\hline $\begin{array}{c}\text { Yuans } \\
\text { hengs } \\
\text { hiji }\end{array}$ & 18.3 & 2.35 & 0.45 & 1.35 & 8000 & 13.76 \\
\hline $\begin{array}{c}\text { Bigui } \\
\text { yuanli } \\
\text { anfati } \\
\text { anhui }\end{array}$ & 18.5 & 3.38 & 0.33 & 0.98 & 8500 & 16.49 \\
\hline $\begin{array}{c}\text { Lianfa } \\
\text { yongr } \\
\text { onghu } \\
\text { afu }\end{array}$ & 20.4 & 2.57 & 0.5 & 1.5 & 12000 & 24.55 \\
\hline
\end{tabular}

\section{E. Analysis of initial data}

First, the original actual data are analyzed. Before optimization, the ratio of green space area, facility area and road area of each real estate to the occupation area is shown in table 4.

$$
\text { proportion of green space }=\frac{\text { green area }}{\text { floor space }}
$$

proportion of facility space $=\frac{\text { facility area }}{\text { floor space }}$

proportion of road space $=\frac{\text { road area }}{\text { floor space }}$

TABLE V. THE ACTUAL GREEN SPACE AREA, FACILITY AREA AND ROAD AREA OF EACH REAL ESTATE ARE RESPECTIVELY PROPORTIONAL TO THE AREA OCCUPIED 


\begin{tabular}{|c|c|c|c|c|}
\hline $\begin{array}{c}\text { Real } \\
\text { estate } \\
\text { name }\end{array}$ & $\begin{array}{c}\text { Proportio } \\
\text { n of } \\
\text { green } \\
\text { space }\end{array}$ & $\begin{array}{c}\text { Proportion } \\
\text { of green } \\
\text { space }\end{array}$ & $\begin{array}{c}\text { Proportion } \\
\text { of road } \\
\text { space }\end{array}$ & $\begin{array}{c}\text { floor } \\
\text { space }\end{array}$ \\
\hline $\begin{array}{c}\text { Huanrun } \\
\text { wanxiang } \\
\text { fu }\end{array}$ & $30 \%$ & $20 \%$ & $18.9 \%$ & 13.7 \\
\hline $\begin{array}{c}\text { Hengdadi } \\
\text { jing }\end{array}$ & $35 \%$ & $20 \%$ & $13.9 \%$ & 9 \\
\hline $\begin{array}{c}\text { Zhonghai } \\
\text { bingjiang } \\
\text { yihao }\end{array}$ & $40 \%$ & $20.1 \%$ & $8.6 \%$ & 6.46 \\
\hline $\begin{array}{c}\text { Yuanshen } \\
\text { gshiji }\end{array}$ & $30.2 \%$ & $20 \%$ & $13.4 \%$ & 6.19 \\
\hline $\begin{array}{c}\text { Biguiyua } \\
\text { nlianfatia } \\
\text { nhui }\end{array}$ & $35.6 \%$ & $20 \%$ & $14.8 \%$ & 6.55 \\
\hline $\begin{array}{c}\text { Lianfayo } \\
\text { ngronghu } \\
\text { afu }\end{array}$ & $40 \%$ & $18.2 \%$ & $11.65 \%$ & 6.61 \\
\hline
\end{tabular}

According to the data, the greenbelt area, facility area, road area and proportion area of each real estate are obtained. It is observed that the proportion of greenbelt area fluctuates between $30 \%$ and $40 \%$, the proportion of facility area fluctuates between $18 \%$ and $20 \%$, and the proportion of road area fluctuates between $10 \%$ and $20 \%$. Excel polyline graph is used to plot the fluctuation range of proportion of green space area, facility area and road area.

Fig. 1. fluctuation range of proportion of green space area, facility area and road area

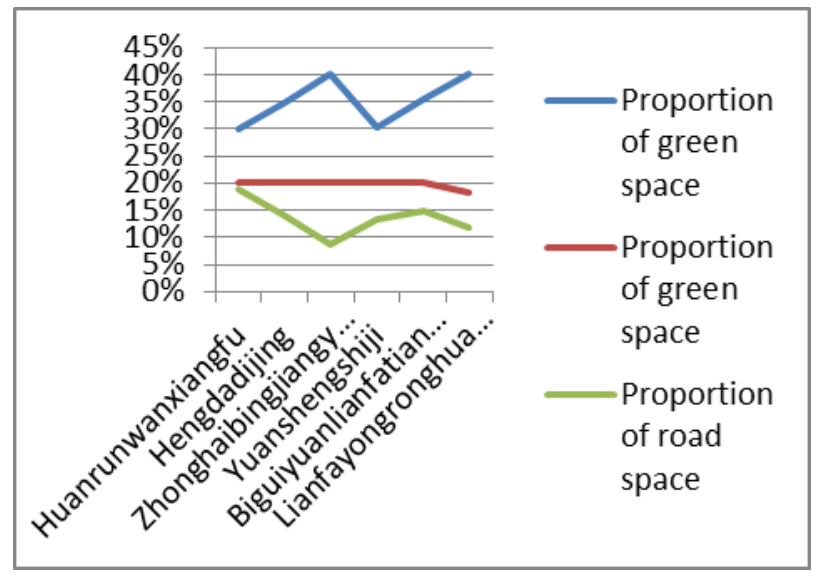

As can be seen from figure 1, the proportion of green space fluctuates around $35 \%$, the proportion of facility area fluctuates around $20 \%$, and the proportion of road area

fluctuates around $15 \%$. Then green area: facility area: road area $=7: 4: 3$.

\section{F. Analysis of initial data}

After optimization, the ratio of green space area, facility area and road area of each real estate to the area of occupation is shown in table 5 .

TABLE VI. THE PROPORTION OF GREEN SPACE AREA, FACILITY AREA AND ROAD AREA OF EACH REAL ESTATE AFTER OPTIMIZATION TO THE AREA OF OCCUPATION

\begin{tabular}{|c|c|c|c|c|}
\hline $\begin{array}{c}\text { Real } \\
\text { estate } \\
\text { name }\end{array}$ & $\begin{array}{c}\text { Proportio } \\
\text { n of green } \\
\text { space }\end{array}$ & $\begin{array}{c}\text { Proportio } \\
\text { n of green } \\
\text { space }\end{array}$ & $\begin{array}{c}\text { Proportio } \\
\text { n of road } \\
\text { space }\end{array}$ & $\begin{array}{c}\text { floor } \\
\text { space }\end{array}$ \\
\hline $\begin{array}{c}\text { Huanrun } \\
\text { wanxiang } \\
\text { fu }\end{array}$ & $38 \%$ & $7.7 \%$ & $22.9 \%$ & 13.7 \\
\hline $\begin{array}{c}\text { Hengdadi } \\
\text { jing }\end{array}$ & $38.9 \%$ & $7.5 \%$ & $22.7 \%$ & 9 \\
\hline $\begin{array}{c}\text { Zhonghai } \\
\text { bingjiang } \\
\text { yihao }\end{array}$ & $46.1 \%$ & $5.9 \%$ & $17.8 \%$ & 6.46 \\
\hline $\begin{array}{c}\text { Yuanshen } \\
\text { gshiji }\end{array}$ & $38 \%$ & $7.3 \%$ & $21.8 \%$ & 6.19 \\
\hline $\begin{array}{c}\text { Biguiyua } \\
\text { nlianfatia } \\
\text { nhui }\end{array}$ & $51.6 \%$ & $5.1 \%$ & $15 \%$ & 6.55 \\
\hline $\begin{array}{c}\text { Lianfayo } \\
\text { ngronghu } \\
\text { afu }\end{array}$ & $38.9 \%$ & $7.6 \%$ & $22.7 \%$ & 6.61 \\
\hline
\end{tabular}

According to the data, the green space area, facility area, road area and proportion area of each real estate are obtained. It is observed that the proportion of green space fluctuates between $38 \%$ and $50 \%$, the proportion of facility area fluctuates between $5 \%$ and $8 \%$, and the proportion of road area fluctuates between $15 \%$ and $25 \%$.According to the data in table 5, excle polyline graph is used to plot the fluctuation range of proportion of green space area, facility area and road area. As shown in figure 2

Fig. 2. fluctuation range of proportion of green space area, facility area and road area 


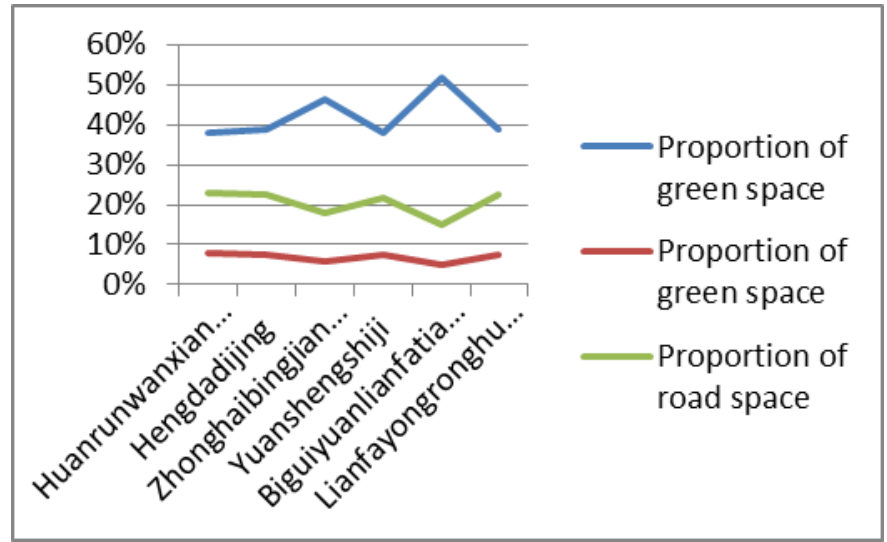

As can be seen from figure 2, the proportion of green space fluctuates around $38 \%$, the proportion of facility area fluctuates around $7 \%$, and the proportion of road area fluctuates around $20 \%$. Then green area: facility area: road area $=5: 1: 3$. It can be found that the ratio of the three is related to per capita green space area, per capita facility area and per capita road area, and it is per capita green space area: per capita facility area: per capita road area $=5: 1: 3$.

\section{CONCLUSION}

According to the solution of the above model, the optimal ratio of green space area, facility area and road area of the optimal model is 5:1:3. In addition, the most reasonable green area accounts for $35 \%$, the facility area accounts for $7 \%$, the road area accounts for $21 \%$, and the rest is the projected area of the building area accounts for $37 \%$.

\section{REASONABLE SUGGESTIONS ON THE PROPORTION OF RESIDENTIAL DISTRICT PLANNING}

According to the model of the problem and the structure studied, from the perspective of residential district planning, some reasonable Suggestions about residential district planning are put forward to the real estate developers and construction departments.

Residential area of the building area is, the greater the profits of real estate developers, the higher the but the construction area, the greater the green area, road area and facilities area is less, comfort to the village inhabitants is reduced, how to guarantee a certain income, under the condition of reasonable planning good small green area, road area and the area of the facility?

The greening of the community is an indispensable part of the planning of the community. People live in a small ecological circle, which needs air, water, plants and animals to form a complete ecological circle. At the same time, the greening environment can increase the comfort of residents. However, a large green area is great, but too large green area squeezes the area of roads, facilities and buildings in the community.
The road in the community is also an indispensable part of the community planning. There are cars in the community and people can pass through. To realize the separation of people and cars, it is necessary to reasonably plan the road area of the community and ensure the access of residents.

Community facilities are also an indispensable part of the community planning. There are various facilities in the community, including basketball court, badminton court and swimming pool. Reasonable planning of some facilities can enrich the life of residents.

The building area is the most important part in the planning of the community, the house can be lived in, the building area is large, the income of the real estate business is high, but buying and selling a house is a two-way transaction, consumer satisfaction is needed, real estate reasonable planning, to achieve the transaction of both sides.

For the investigation of six different real estate projects in ganzhou, we found out the reasonable ratio of the planned residential area. Therefore, we made the following reasonable Suggestions for the residential area:

1. Do not blindly pursue the expansion of the construction area, and reasonably allocate the proportion of the construction area to about 37\%, which still has considerable income.

2. The reasonable ratio of planning residential area is: green area: road area: facility area: 5:1:3.

3. Green space area, road area and facility area shall be reasonably allocated according to the land area, accounting for $35 \%, 7 \%$ and $21 \%$ of the land area respectively.

\section{REFERENCES}

[1] Li Z., Chen H., Liu F. (2019) Practice and Research on the Modern Residential District Planning and Design. In: Long S., Dhillon B. (eds) Man-Machine-Environment System Engineering. MMESE 2019. Lecture Notes in Electrical Engineering, vol 576. Springer, Singapore

[2] Jerker Nilsson. Tenants' participation - A study of residential service planning. Journal of Consumer Policy,1977,1(3).

[3] Yang L, Qian F, Zhao D. Analysis of the modern residential district planning and design. Alexandria Engineering Journal, 2016:S1110016816000053.

[4] Li Z, Liu F. Research on residential environment planning and design in the post-earthquake reconstruction[C]// International Conference on Information Systems for Crisis Response \& Management IEEE, 2012.

[5] Chen Y R, Meng C L. The Planning and Design of the Modern Residential Area from Green Building Perspective: Taking Chengxi Project of Taiyuan as an Example. Applied Mechanics and Materials, 2013, 275-277.

[6] Jin H, Zheng R. Research on Planning and Design of HIFAl"s New Campus. Applied Mechanics and Materials, 2014, 644-650:5606-5610.

[7] Qi C. Landscape Planning and Design of Residential District with Cultural and Ecological. Heilongjiang Agricultural Sciences, 2014. 